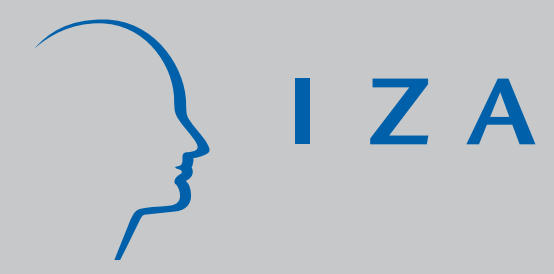

IZA DP No. 3398

Brain Drain and its Determinants:

A Major Issue for Small States

Michel Beine

Frédéric Docquier

Maurice Schiff

March 2008 


\title{
Brain Drain and its Determinants: A Major Issue for Small States
}

\author{
Michel Beine \\ University of Luxembourg \\ Frédéric Docquier \\ FNRS, IRES, Catholic University of Louvain \\ and IZA \\ Maurice Schiff \\ World Bank and IZA
}
Discussion Paper No. 3398
March 2008

\author{
IZA \\ P.O. Box 7240 \\ 53072 Bonn \\ Germany \\ Phone: +49-228-3894-0 \\ Fax: +49-228-3894-180 \\ E-mail: iza@iza.org
}

\begin{abstract}
Any opinions expressed here are those of the author(s) and not those of IZA. Research published in this series may include views on policy, but the institute itself takes no institutional policy positions.

The Institute for the Study of Labor (IZA) in Bonn is a local and virtual international research center and a place of communication between science, politics and business. IZA is an independent nonprofit organization supported by Deutsche Post World Net. The center is associated with the University of Bonn and offers a stimulating research environment through its international network, workshops and conferences, data service, project support, research visits and doctoral program. IZA engages in (i) original and internationally competitive research in all fields of labor economics, (ii) development of policy concepts, and (iii) dissemination of research results and concepts to the interested public.
\end{abstract}

IZA Discussion Papers often represent preliminary work and are circulated to encourage discussion. Citation of such a paper should account for its provisional character. A revised version may be available directly from the author. 
IZA Discussion Paper No. 3398

March 2008

\section{ABSTRACT \\ Brain Drain and its Determinants: A Major Issue for Small States}

This paper examines the relationship between the brain drain and country size, as well as the extent of small states' overall loss of human capital. We find that small states are the main losers because they i) lose a larger proportion of their skilled labor force and ii) exhibit stronger reactions to standard push factors. We also observe that the correlation between human capital indicators and country size is close to zero. This suggests that small states are more successful in producing skilled natives and less successful in retaining them.

JEL Classification: F22, J24, J61, O15

Keywords: $\quad$ brain drain, small states, human capital, openness

Corresponding author:

Maurice Schiff

DECRG (MC3-303)

World Bank

1818 H Street NW

Washington, DC 20433

USA

E-mail: mschiff@worldbank.org

\footnotetext{
* This paper is a product of the Economic Policy and Debt Department of the World Bank, which launched a Research Program on Economic Growth and Integration of Small States to the World Economy (World Bank contract PO.0007674813). It was presented at the World Bank Conference on "Small States, Growth Challenges and Development Solutions", Washington, 7-8 December 2007. We thank David McKenzie and Edgardo Favaro for their comments. The views presented here are those of the authors and do not necessarily reflect those of the World Bank, its Executive Directors or the governments they represent.
} 


\section{INTRODUCTION}

Source countries have been faced with a rising tide of skilled labor emigration in recent years, a contributing factor being the increasing skilled labor bias in host countries' immigration policies. This issue is particularly acute in small developing countries. Given the importance of human capital in the growth process (Lucas 1988), a substantial brain drain might seriously hamper the development of countries affected by it.

This paper examines various empirical models of skilled emigration rates and assesses the specific role of country size. Section 1 defines the concept of "small states" used in our empirical analysis, describes some of their characteristics, and provides evidence on the brain drain. Section 3 presents the empirical model and results. Section 4 concludes.

\section{SMALL STATES}

Section 1.1 provides a definition of "small states" and some of their characteristics, and Section 1.2 presents brain drain figures for small states and other countries.

\subsection{DEFINITION}

There is no special significance in the selection of a particular population threshold to define small states. Indeed, the Commonwealth, in its work on small states, uses a threshold of 1.5 million people, but it also includes larger member countries (Jamaica, Lesotho, Namibia and Papua New Guinea) because they share many of the same characteristics of smallness. The World Bank Task Force on small states used the same threshold as a convenient yardstick for classifying all small states, and only considers sovereign states.

Using the standard of a population below 1.5 million people in 2000, 45 developing countries are small, accounting for nearly one third of the total number of developing countries. They are home to 20 million people, less than 0.4 percent of the total population of developing countries. They range in size from "micro-states” like Cook Islands, Nauru, Niue, 
Palau, St. Kitts and Nevis, and Tuvalu (with fewer than 50,000 people each) to Botswana, Gabon, The Gambia, Guinea-Bissau, Mauritius, and Trinidad and Tobago (with more than 1 million people each).

The per capita GNP in these countries also ranges widely, from less than \$400 in several African countries (Comoros, The Gambia, Guinea-Bissau, and Sao Tome and Principe), to \$700-1,300 in such countries as Cape Verde, Guyana, Kiribati, Maldives, Solomon Islands, and Tuvalu; to more than \$9,000 (The Bahamas, Brunei, Cyprus, Malta, and Qatar). There are small states in every geographic region, but most countries fall into three main groups: twelve states are in the Caribbean region, fourteen in East Asia and Pacific, and twelve in Africa. Of the remaining seven countries, two are in South Asia, two in the Middle East, and three in Europe.

\subsection{BRAIN DRAIN}

Brain drain figures are presented in Table 1. These are based on Docquier and Marfouk (2006). The table presents skilled and overall emigration rates in 2000, as well as the ratio of the former to the latter (the "schooling gap”), for 46 small developing states - defined by the UN as states with population below 1.5 million - and for other categories of interest. Skilled workers are defined as those with university education.

Row 1 of Table 1 shows that small developing states experience an extremely high level of brain drain (43.2\%). In other words, 3 out of every 7 individuals with university education live outside their country of origin. This rate is 2.8 times as large as the $15.3 \%$ overall migration rate.

\section{[Table 1 about here]}

The table also shows a brain drain for small (all) high-income states of 23\% (3.5\%) or a ratio of 6.5 for small versus all states. The same ratio for small versus all developing countries is $(43.2$ / 7.4) or close to 6 . In other words, the impact of country size on the brain 
drain seems robust across a wide range of incomes. Moreover, the brain drain for all developing countries (7.4\%) is over twice that of high-income countries (3.5\%) and the schooling gap is close to four times as high (4.9\% versus $1.3 \%)$.

The region with the highest small-state brain drain (74.9\%) is the Caribbean (in "Latin America and the Caribbean”), followed by East Asia and Pacific region (mainly the South Pacific islands) with a brain drain of 50.8\%, and Sub-Saharan Africa is next with $41.7 \%$, with several countries over $60 \%$.

Thus, as far as small states are concerned, three out of four skilled Caribbean individuals live outside their country of origin, two out of four in East Asia and Pacific, and two out of five in Sub-Saharan Africa. Though Sub-Saharan Africa has the lowest brain drain among these three regions, its schooling gap is more than double that in East Asia and Pacific and over three times that in Latin America and the Caribbean. Sub-Saharan high schooling gap is due mainly to the wider income gap with developed countries and the smaller share of skilled individuals in the population.

\section{EMPIRICAL MODEL}

The empirical model is presented in Section 2.1, the definition of the two migration rates in Section 2.2, and the definition of the explanatory variables in Section 2.3.

\subsection{MODEL}

To estimate the determinants of the brain drain, we regress the rate of emigration of skilled workers on various potential determinants observed in 1990 and 2000. Many economic and non-economic factors are likely to explain migrants' decisions. The empirical literature puts forward that emigration rates depend on many push factors at origin, pull factors at destination, cultural and geographic distance and immigration policies. Our general model is: 


$$
\begin{aligned}
m_{i t}^{s}= & a_{i}+a_{1} \times G D P_{i t}+a_{2} \times G D P_{i t}^{2}+a_{3} \times D I S T_{i}+a_{4} \times C O L_{i}+a_{5} \times L_{I N G} \\
& +a_{6} \times F_{i t} C_{i t}+a_{7} \times P O L_{i t}+a_{8} \times S I Z E_{i t}+\varepsilon_{i t}
\end{aligned}
$$

Let us now describe the variables used in this regression and explain the econometric methodology.

\subsection{MIGRATION RATES}

Our analysis relies on the data set developed by Docquier and Marfouk (2006). The construction of the database relies on three steps: (i) collecting Census and register information on the structure of immigration in all OECD countries; (ii) summing up over OECD host countries, enabling us to determine the stock of immigrants from any sending country to the OECD area by education level; and (iii) comparing the educational structure of emigration to that of the population remaining at home, so as to compute emigration rates by educational attainment in 1990 and $2000^{1}$. The emigration "rate" of skill $s=l, h(l=$ low, $h$ $=$ high $)$ from country $i$ at time $t$ is defined as the ratio of emigrants $\left(E M_{i, t}^{s}\right)$ to natives or the sum of residents $\left(N_{i, t}^{s}\right)$ and emigrants $\left(E M_{i, t}^{s}\right)$, i.e.,

$$
m_{i, t}^{s}=\frac{E M_{i, t}^{s}}{N_{i, t}^{s}+E M_{i, t}^{s}} .
$$

Counting all foreign born individuals as immigrants independently of their age at arrival, the Docquier and Marfouk (2006) database does not account for where the education took place. ${ }^{2}$ Beine et al.(2006) consider the emigration of skilled natives who obtained their university degree in their country of origin. They use the immigrants' age of entry as a proxy for where education was acquired. Our regressions also use a definition of the brain drain that excludes people who migrated before age 22 (i.e., it excludes those who obtained or completed their tertiary degree abroad). 
Our emigration rates are based on the 1990 and 2000 stocks, and thus refer to past and recent migration decisions. Consequently, we use long-run averages for the explanatory variables when available

\subsection{EXPLANATORY VARIABLES}

Many economic and non-economic factors are likely to explain migrants' destination choices. The empirical literature puts forth that emigration rates depend on many push factors at origin, pull factor at destination, distances (cultural and geographic) and immigration policies. To explain aggregate emigration rates, we use the following controls:

GDP per capita and its squared value $\left(G D P_{i}, G D P_{i}^{2}\right)$ of the source country are used. The neoclassical model of migration predicts that a rise in GDP per capita in the country of origin reduces the incentive to emigrate. However, as shown by Lopez and Schiff (1998) and Rotte and Vogler (2000), economic growth in developing countries might lead to more migration because of a relaxation of financial restrictions, even if income differentials to destination countries decrease. Introducing the square of GDP per capita allows us to capture such effects. We use the World Development Indicators (World Bank, 2005b) and compute the 1975-2000 average GDP per capita level.

Geographical distance between countries of origin and destination raise migration costs. The variable used is the log of distance to the closest OECD country ( $D I S T_{i}$ ), measured in kilometers. It comes from the CEPII data set which is based on population-weighted bilateral distances between the biggest cities at origin and destination (see Clair et al., 2004).

Colonial links tend to lower the cultural distance between host countries and their former colonies, including superior knowledge and information on the destination country, resulting in lower migration costs. In order to capture this effect, we use a dummy variable 
$\left(C O L_{i}\right)$ which equals 1 if the origin country had a colonial relationship with an OECD country. We use the CIA World Factbook to build this dummy variable.

Linguistic proximity clearly favors the exchange of labor between countries. Skills acquired prior to migration are not equally transferable to all potential host countries. The return to foreign human capital is higher in countries sharing the same language or having the same education system. The literature on migrants' assimilation reveals that migrants obtain a substantial return for their language capacity, especially skilled migrants. Chiswick and Miller (2002, 2004) found a strong correlation between language skill and immigrants' earnings. We construct a dummy variable ( $L I N G_{i}$ ) equal to one when the origin country shares a common language with countries where economic immigration programs are quantitatively important (USA, Canada, Australia and New Zealand).

We also control for ethnic diversity in origin countries by using religious, linguistic and ethnic fractionalization indicators $\left(F R A C_{i}\right)$. Such fractionalization may impact the psychic costs of migration (relative to non-migration) and affect the desire of people to leave their country. This is especially true in developing countries where fractionalization often gives rise to ethnic or religious conflicts. Our data are taken from Alesina and al. (2003).

The socio-political environment at origin $\left(P O L_{i}\right)$ also acts as a push factor. The measures used come from two data sets on governance and economic freedom. Data on governance are given in Kaufmann et al. (2003) for 1996, 1998, 2000, 2002 and 2004. From the six available indicators, we use "political stability and absence of violence" and “government effectiveness". The first indicator measures "perceptions of the likelihood that the government in power will be destabilized or overthrown by possibly unconstitutional and/or violent means, including domestic violence and terrorism”. The second indicator measures "quality of public service provision, the quality of the bureaucracy, the competence 
of civil servants, the independence of the civil service from political pressures, and the credibility of the government's commitment to policies". Both are normally distributed between -2.5 (bad governance) and 2.5 (good governance). For each country, we average the scores over the years where they are available. Regarding economic freedom, we use one component of the general index published by the Heritage Foundation, namely the indicator of property rights available from 1995 to 2005. This variable ranges from 1.0 in countries where property rights are well preserved to 4.0 in countries where they are violated. For each country, we average all the available scores.

The size of the country of origin is likely to affect its openness. In our regressions, we use the 1975-2000 log of the population size $\left(S I Z E_{i}\right)$. To capture the specific behavior of small countries, we also use additional dummies for small states $\left(S M S_{i}\right)$ (population lower than 1.5 million) and subsets of this group. Population data come from the World Development Indicators (World Bank, 2005).

In alternative regressions, we test for interaction terms between small states, fractionalization and GDP per capita so as to evaluate the specific elasticity of small states' emigration rates to push factors.

The model described by equation (1) can be estimated using usual panel data techniques. Fixed effects estimation that account for unobserved heterogeneity (i.e. different $\alpha_{i}$ across countries) does not make sense here because most of the explanatory variables are time invariant. Therefore, we rely on two alternative techniques: (i) random effects estimation that accounts for unobserved heterogeneity and allows us to estimate the impact of time invariant variables; and (ii) pooled least squares (PLS) that consider no specific constant for each country in equation (1). 


\section{RESULTS}

In this paper, we consider the role of country size and smallness in two different ways. First, as mentioned previously, we look at the impact of size and smallness on the degree of openness. The analysis is carried out for the different types of migration considered here. Table 1 looks at the behavior of total migration while Tables 2 and 3 examine, respectively, the determinants of the brain drain measured as the proportion of skilled migrants abroad (whatever their age at migration), and as the proportion of skilled migrants who left after age 22 (i.e., after tertiary education).

Second, we investigate whether and to what extent migrants coming from small countries behave differently in terms of their response to religious fractionalization (RF) (Table 4) and to GDP capita (Tables 5 and 6). This is done by introducing interaction terms between the "small states" dummy and RF, and between the former and GDP per capita (and GDP per capita squared).

\subsection{IMPACT OF SIZE AND SMALLNESS}

We adopt a general-to-specific econometric approach. We first estimate the model using panel data estimation with random effects with all potential determinants included in the regression. Columns 1 and 2 of Tables 2 to 4 use two different ways to capture smallness of countries. Column 1 includes dummies for countries with less than 1.5 million inhabitants and countries with more than 40 millions. In Column 2, the classification of small countries is further split between countries with less than and more than, 0.5 million inhabitants. Column 3 presents a parsimonious specification in which the non-significant variables (such as the large state dummy) are deleted. Finally, as a robustness check on the use of random effects estimates, we estimate the same model using PLS (Column 4). 
Tables 2 to 4 present a number of interesting results. First, as expected, an increase in the population size reduces total and skilled emigration rates. Second, we find an additional role of smallness beyond that of population size. The dummy for small states (in Column 1) turns out to be significantly positive for all types of migration examined. We further split this dummy (Column 2) and show that this result is in fact driven by the very small states, i.e. those with a population below 0.5 million inhabitants. This result is very robust across migration types and regression techniques.

Second, we find the usual inverted-U relationship between migration and GDP per capita in origin countries. This result has been found in the literature (e.g., Rotte and Vogler, 2000, and Mayda, 2006). At low levels, income has a positive impact on the migration rate since it alleviates liquidity constraints. As income increases further, the income difference with the destination countries falls, which reduces the incentive to migrate ${ }^{3}$. This result is found for the three migration types.

Some other determinants also tend to exert significant influence. Violation of property rights seems acts as a push factor, especially for total migration. Political instability also acts as a push factor, especially for skilled migrants. Government effectiveness seems to favor migration, which might seem counterintuitive. ${ }^{4}$ Some caution is nevertheless required when looking at the results of these three political variables. The reason is that they are strongly correlated, which raises the issue of collinearity in the regressions reported in the first two columns of Tables 2, 3 and 4. To account for that, we delete two of the three variables in the parsimonious regressions. The results show that these variables do not turn out to be robust determinants of skilled migration (Tables 3 and 4) though they are significant for the total migration rate (Table 2). In contrast, religious fractionalization seems to be a robust determinant, though mainly for skilled migration. 
Usual variables such as linguistic proximity, distance and colonial links also appear to be robust. The significance of the dummy for the year 2000 reflects a moderate but general increase in the rates of skilled migration between 1990 and 2000.

\section{[Tables 2, 3 and 4 about here]}

\subsection{THE BEHAVIOR OF SMALL STATES’ MIGRANTS}

We now turn to the issue of the specific behavior of small states' migrants. We address this issue by creating interaction variables between the small states dummy (capturing countries with less than 1.5 millions inhabitants) and three variables that turn out to be highly significant and robust in the previous regressions: (i) religious fractionalization that was found to be a push factor for skilled migration; (ii) GDP per capita (in level) capturing the impact of liquidity constraints; and (iii) squared GDP per capita capturing the reduced incentive to migrate above a given threshold of income. Since these interaction terms are highly correlated with each other as well as with the variable small states itself, they are included in separate regressions. In other words, joint estimation is not feasible due to the high degrees of collinearity between these variables. The results are shown in Tables 5 to 7.

Estimates in Table 5 suggest that small states are much more sensitive to religious fractionalization (RF). Note that the variable is only significant for skilled migrants while the additional impact in small states is significant at the $1 \%$ level for both skilled and unskilled migrants. As indicated by both the coefficient of RF and of the interaction variable (Rel. Frac. $x$ Small), for a given level of fractionalization, people in small states are at least three times more willing to migrate than those of other countries.

\section{[Table 5 about here]}


Estimates of Table 6 provide a similar qualitative picture with respect to GDP per capita. That is, as suggested by the negative and significant values of the coefficients of the interaction term (GDP per cap x small), small states workers' migration is more sensitive to changes in GDP per capita. This result is quite robust across migration types and across estimation techniques, and is consistent with the view that migration costs might be lower in small states than in other countries. Nevertheless, the difference in the impact of small states and other ones is negligible, ranging from approximately $1 \%$ to $2 \%$.

\section{[Table 6 about here]}

As for GDP per capita squared (Table 7), we find that the difference between small states and others in terms of the impact of per capita GDP squared is statistically significant, with a smaller impact for small states. Once again, though, the difference is small empirically, ranging from less than $2 \%$ to less than $5 \%$.

Thus, it is only with respect to religious fractionalization that the sensitivity of small states’ migrants is substantially greater than that for other countries.

\section{[Table 7 about here]}

\section{THE SMALL STATE PUZZLE}

Even though small states lose a larger proportion of their skilled labor force, the correlation between human capital indicators and country size is close to zero (the regression coefficient is positive but not significantly different from zero). This implies that the average level of education small states generate is higher than in other countries.

Why would education be higher in small states? 
- Easterly and Kraay (1999) found that, controlling for location, smaller states actually have a higher per capita GDP than other states. Lower liquidity constraints might explain why young people invest more in education in small states.

- Small states might have more generous education policies and/or benefit from the outsourcing of education given their geographical and linguistic proximity with large and rich developed countries (e.g., between Caribbean countries and the USA, and between Pacific islands and both Australia and New Zealand).

- Skilled migration prospects raise the return to education and result in a brain gain, i.e., in additional investment in education (Beine et al. 2001, 2007). Estimates by Beine et al (2007) suggest that the brain gain is equal to about half the brain drain in small developing states, so that the actual (net) loss of human capital is equal to only half the brain drain level. This means that the proportion of educated would be 20 to 30 percent higher in small states in the absence of the brain drain.

\section{CONCLUSION}

The analysis provided in this paper has shown that small states are the main losers from the brain drain because of the negative impact of country size, the additional positive impact of being a small state, and because of the skilled migrants' greater sensitivity to standard push factors. Unfortunately, there seem to be few policy options available that can help seriously dampen the extent of the brain drain. One option source countries might want to consider is the formation of cooperative arrangements with their principal destination countries, including agreements on return, and possibly circular, migration. 


\section{REFERENCES}

Alesina, A., A. Devleeschauwer, W. Easterly, S. Kurlat and R. Wacziard (2003), “Fractionalization”, Journal of Economic Growth, 8, 155-194.

Beine, M., F. Docquier and H. Rapoport (2007),” Brain drain and human capital formation in developing countries: winners and losers”, Economic Journal.

Beine, M., F. Docquier and H. Rapoport, (2007), Measuring international skilled migration: new estimates controlling for age of entry, World Bank Economic Review.

Chiswick, B.R., Y. L. Lee, P. W. Miller (2002), "The Determinants of the Geographic Concentration among Immigrants: Application to Australia", IZA DP No 462, Bonn.

Chiswick , B.R. and P. W. Miller (2004), "Where Immigrants Settle in the United States?", Journal of Comparative Policy Analysis, 6(2), p.p. 185-197

Clair, G., G. Gaullier, Th. Mayer and S. Zignago (2004), “A note on CEPII’s distances measures”, Explanatory note, CEPII, Paris.

Docquier, F. and E. Lodigiani (2006), “Skilled migration and business networks”, Mimeo, Université Catholique de Louvain.

Docquier, F. et A. Marfouk (2006), ”International migration by educational attainment (19902000)”, in: Ozden, C. et M. Schiff (eds), International Migration, Remittances and the Brain Drain, Chap. 5, Palgrave-Macmillan.

Dumont, J.C. and Lemaître G. (2004),"Counting immigrants and expatriates in OECD countries: a new perspective”, Mimeo, OECD.

Easterly, W. and A. Kraay (1999), "Small states, small problems?", Policy Research Working Paper Series, n. 2139, World Bank. 
Kaufmann, D., A. Kraay, and M. Mastruzzi (2003), “Governance Matters III: Governance Indicators for 1996-2002”, World Bank Policy Research Working Paper 3106.

Kugler, M. and H. Rapoport (2006), "Migration and FDI: complements or substitutes?", paper presented at the CEPR/ESF conference on "Outsourcing, Migration, and the European Economy", Rome. <http://www.cepr.org/meets/wkcn/4/4556/papers/Rapoport.pdf>.

Lopez, R. and M. Schiff (1998), "Migration and the Skill Composition of the Labor Force: The Impact of Trade Liberalization in LDCs", Canadian Journal of Economics 31 (2): 318-36. Lucas, R.E., Jr. (1988), “The Mechanics of Economic Development” Journal of Monetary Economics.

Mayda, A.M (2006), International Migration : a Panel Data Analysis of the Determinants of Bilateral Flows, Unpublished paper, Georgetown University.

Pedersen, P.J., M. Pytlikova and N. Smith (2004), “Selection or Network Effects? Migration Flows into 27 OECD Countries, 1990-2000”, IZA Discussion Paper, No 1104, Bonn.

Rotte and M. Vogler (2000), " The Effects of Development on Migration: Theoretical Issues and New Empirical Evidence", Journal of Population Economics, 13(3), 485-508.

World Bank (2005), World Development indicators, World Bank - Washington.

Wooldridge, J.M. (2002), Econometric Analysis of Cross Section and Panel Data, The MIT Press - Cambridge. 
Table 1: Emigration rates (\%) by country group

\begin{tabular}{|c|c|c|c|c|}
\hline & & \multicolumn{3}{|c|}{2000} \\
\hline & $\mathbf{N}$ & $\begin{array}{c}\text { Skilled emigration } \\
\text { rate }\end{array}$ & $\begin{array}{c}\text { Average } \\
\text { emigration } \\
\text { rate }\end{array}$ & Schooling gap \\
\hline $\begin{array}{l}\text { Small States (pop }<1.5 \\
\text { million) } \\
\text { by population size }\end{array}$ & 46 & 43.2 & 15.3 & 2.81 \\
\hline Population from 0 to 0.5 million & 32 & 41.7 & 21.0 & 2.0 \\
\hline Population from 0.5 to 1 million & 8 & 47.2 & 15.7 & 3.0 \\
\hline $\begin{array}{c}\text { Population from } 1 \text { to } 1.5 \text { million } \\
\text { by region / income }\end{array}$ & 6 & 40.9 & 9.8 & 4.2 \\
\hline East Asia and Pacific & 12 & 50.8 & 17.0 & 3.0 \\
\hline Latin America and Caribbean & 10 & 74.9 & 35.0 & 2.1 \\
\hline Sub-Saharan Africa & 10 & 41.7 & 6.0 & 6.9 \\
\hline High-income countries & 12 & 23.0 & 10.7 & 2.1 \\
\hline Other Groups of Interest & & & & \\
\hline Small Islands Developing States & 37 & 42.4 & 13.8 & 3.1 \\
\hline Population from 1.5 to 3 million & 15 & 20.9 & 7.1 & 3.0 \\
\hline Population from 3 to 4 million & 13 & 18.5 & 10.0 & 1.8 \\
\hline World average & 192 & 5.3 & 1.8 & 3.0 \\
\hline Total high-income countries & 41 & 3.5 & 2.8 & 1.3 \\
\hline Total developing countries & 151 & 7.4 & 1.5 & 4.9 \\
\hline
\end{tabular}

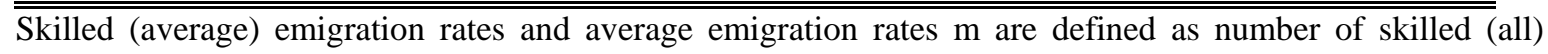
migrants divided by the sum of skilled (all) migrants.

Schooling gap $=$ Skilled emigration rate/Average emigration rate .

Source : Docquier and Marfouk (2006). 
Table 2: Determinants of the total emigration rate

\begin{tabular}{|c|c|c|c|c|}
\hline & (1) & (2) & (3) & (4) \\
\hline Log population size & $\begin{array}{c}-0.258 \\
(2.78)^{* * *}\end{array}$ & $\begin{array}{c}-0.266 \\
(3.02)^{* * *}\end{array}$ & $\begin{array}{c}-0.237 \\
(3.52)^{* * *}\end{array}$ & $\begin{array}{c}-0.254 \\
(4.98)^{* * *}\end{array}$ \\
\hline Log GDP per capita & $\begin{array}{c}5.888 \\
(5.34)^{* * *}\end{array}$ & $\begin{array}{c}6.141 \\
(5.59)^{* * *}\end{array}$ & $\begin{array}{c}6.071 \\
(5.59)^{* * *}\end{array}$ & $\begin{array}{c}8.422 \\
(7.40)^{* * *}\end{array}$ \\
\hline Log GDP per capita squared & $\begin{array}{c}-0.335 \\
(4.88)^{* * *}\end{array}$ & $\begin{array}{c}-0.350 \\
(5.11)^{* * *}\end{array}$ & $\begin{array}{c}-0.349 \\
(5.15)^{* * *}\end{array}$ & $\begin{array}{c}-0.503 \\
(7.02)^{* * *}\end{array}$ \\
\hline Oil exporting dummy & $\begin{array}{l}-0.406 \\
(1.18)\end{array}$ & $\begin{array}{l}-0.336 \\
(0.97)\end{array}$ & & \\
\hline Violation of property rights & $\begin{array}{c}0.546 \\
(2.90)^{* * *}\end{array}$ & $\begin{array}{c}0.504 \\
(2.70)^{* * *}\end{array}$ & $\begin{array}{c}0.528 \\
(2.86)^{* * *}\end{array}$ & $\begin{array}{c}0.424 \\
(3.00)^{* * *}\end{array}$ \\
\hline Political stability & $\begin{array}{l}-0.273 \\
(1.27)\end{array}$ & $\begin{array}{l}-0.277 \\
(1.29)\end{array}$ & & \\
\hline Government effectiveness & $\begin{array}{c}0.750 \\
(2.62)^{* * *}\end{array}$ & $\begin{array}{c}0.725 \\
(2.55)^{* *}\end{array}$ & $\begin{array}{c}0.575 \\
(2.45)^{* *}\end{array}$ & $\begin{array}{c}0.688 \\
(3.71)^{* * *}\end{array}$ \\
\hline Religious fractionalization & $\begin{array}{l}0.348 \\
(0.83)\end{array}$ & $\begin{array}{l}0.435 \\
(1.03)\end{array}$ & $\begin{array}{l}0.448 \\
(1.07)\end{array}$ & $\begin{array}{c}0.599 \\
(1.92)^{*}\end{array}$ \\
\hline Linguistic links & $\begin{array}{c}0.721 \\
(3.25)^{* * *}\end{array}$ & $\begin{array}{c}0.679 \\
(3.08)^{* * *}\end{array}$ & $\begin{array}{c}0.755 \\
(3.53)^{* * *}\end{array}$ & $\begin{array}{c}0.649 \\
(4.10)^{* * *}\end{array}$ \\
\hline Log distance from OECD & $\begin{array}{c}-0.602 \\
(5.76)^{* * *}\end{array}$ & $\begin{array}{c}-0.594 \\
(5.70)^{* * *}\end{array}$ & $\begin{array}{c}-0.608 \\
(5.89)^{* * *}\end{array}$ & $\begin{array}{c}-0.662 \\
(8.34)^{* * *}\end{array}$ \\
\hline Former colony of OECD country & $\begin{array}{l}0.308 \\
(1.20)\end{array}$ & $\begin{array}{l}0.340 \\
(1.37)\end{array}$ & $\begin{array}{l}0.337 \\
(1.41)\end{array}$ & $\begin{array}{l}0.228 \\
(1.24)\end{array}$ \\
\hline Year 2000 & $\begin{array}{c}0.328 \\
(6.85)^{* * *}\end{array}$ & $\begin{array}{c}0.332 \\
(6.97)^{* * *}\end{array}$ & $\begin{array}{c}0.331 \\
(7.09)^{* * *}\end{array}$ & $\begin{array}{c}0.293 \\
(2.04)^{* *}\end{array}$ \\
\hline Small states $(<1.5)$ & $\begin{array}{l}0.647 \\
(1.68)\end{array}$ & & & \\
\hline Large states $(>40)$ & $\begin{array}{l}-0.015 \\
(0.07)\end{array}$ & $\begin{array}{c}-0.018 \\
(0.08)\end{array}$ & & \\
\hline Small states A (from 0 to .5) & & $\begin{array}{c}1.000 \\
(1.96)^{* *}\end{array}$ & $\begin{array}{c}0.988 \\
(2.06)^{* *}\end{array}$ & $\begin{array}{c}1.027 \\
(2.92)^{* * *}\end{array}$ \\
\hline Small states B (from .5 to 1.5 ) & & $\begin{array}{l}0.052 \\
(0.22)\end{array}$ & & \\
\hline Constant & $\begin{array}{c}-23.353 \\
(5.14)^{* * *}\end{array}$ & $\begin{array}{c}-24.188 \\
(5.28)^{* * *}\end{array}$ & $\begin{array}{c}-24.251 \\
(5.37)^{* * *}\end{array}$ & $\begin{array}{c}-31.827 \\
(6.99)^{* * *}\end{array}$ \\
\hline No. of Observations & 285 & 285 & 285 & 285 \\
\hline No. of Countries & 153 & 153 & 153 & 153 \\
\hline R-squared & 0.51 & 0.52 & 0.51 & 0.52 \\
\hline
\end{tabular}

Absolute value of t statistics in parentheses

*significant at $10 \%$; **significant at $5 \%$; ***significant at $1 \%$

Columns (1) to (3): panel random effects estimation; column (4): Pooled Least Squares estimation 
Table 3: Determinants of the skilled emigration rate

\begin{tabular}{|c|c|c|c|c|}
\hline & (1) & (2) & (3) & $(4)$ \\
\hline Log population size & $\begin{array}{l}-0.191 \\
(1.94)^{*}\end{array}$ & $\begin{array}{c}-0.220 \\
(2.32)^{* *}\end{array}$ & $\begin{array}{c}-0.208 \\
(2.95)^{* * *}\end{array}$ & $\begin{array}{c}-0.246 \\
(4.56)^{* * *}\end{array}$ \\
\hline Log GDP per capita & $\begin{array}{c}4.980 \\
(4.07)^{* * *}\end{array}$ & $\begin{array}{c}5.288 \\
(4.31)^{* * *}\end{array}$ & $\begin{array}{c}4.454 \\
(3.70)^{* * *}\end{array}$ & $\begin{array}{c}4.352 \\
(3.78)^{* * *}\end{array}$ \\
\hline Log GDP per capita squared & $\begin{array}{c}-0.311 \\
(4.07)^{* * *}\end{array}$ & $\begin{array}{c}-0.329 \\
(4.29)^{* * *}\end{array}$ & $\begin{array}{c}-0.272 \\
(3.65)^{* * *}\end{array}$ & $\begin{array}{c}-0.274 \\
(3.83)^{* * *}\end{array}$ \\
\hline Oil exporting dummy & $\begin{array}{l}-0.457 \\
(1.31)\end{array}$ & $\begin{array}{l}-0.398 \\
(1.13)\end{array}$ & & \\
\hline Violation of property rights & $\begin{array}{c}0.554 \\
(2.91)^{* * *}\end{array}$ & $\begin{array}{c}0.497 \\
(2.63)^{* * *}\end{array}$ & $\begin{array}{l}0.148 \\
(0.99)\end{array}$ & $\begin{array}{l}0.100 \\
(0.78)\end{array}$ \\
\hline Political stability & $\begin{array}{l}-0.366 \\
(1.69) *\end{array}$ & $\begin{array}{l}-0.366 \\
(1.69) *\end{array}$ & & \\
\hline Government effectiveness & $\begin{array}{c}0.991 \\
(3.39)^{* * *}\end{array}$ & $\begin{array}{c}0.946 \\
(3.25)^{* * *}\end{array}$ & & \\
\hline Religious fractionalization & $\begin{array}{c}0.910 \\
(2.16)^{* *}\end{array}$ & $\begin{array}{c}0.982 \\
(2.31)^{* *}\end{array}$ & $\begin{array}{c}1.070 \\
(2.45)^{* *}\end{array}$ & $\begin{array}{c}1.184 \\
(3.58)^{* * *}\end{array}$ \\
\hline Linguistic links & $\begin{array}{c}0.826 \\
(3.69)^{* * *}\end{array}$ & $\begin{array}{c}0.766 \\
(3.44)^{* * *}\end{array}$ & $\begin{array}{c}0.831 \\
(3.71)^{* * *}\end{array}$ & $\begin{array}{c}0.700 \\
(4.18)^{* * *}\end{array}$ \\
\hline Log distance from OECD & $\begin{array}{c}-0.387 \\
(3.66)^{* * *}\end{array}$ & $\begin{array}{c}-0.379 \\
(3.58)^{* * *}\end{array}$ & $\begin{array}{c}-0.463 \\
(4.37)^{* * *}\end{array}$ & $\begin{array}{c}-0.465 \\
(5.59) * * *\end{array}$ \\
\hline Former colony of OECD country & $\begin{array}{c}0.935 \\
(3.60)^{* * *}\end{array}$ & $\begin{array}{c}1.007 \\
(3.98)^{* * *}\end{array}$ & $\begin{array}{c}1.013 \\
(4.01)^{* * *}\end{array}$ & $\begin{array}{c}0.763 \\
(3.92)^{* * *}\end{array}$ \\
\hline Year 2000 & $\begin{array}{c}0.217 \\
(3.79)^{* * *}\end{array}$ & $\begin{array}{c}0.225 \\
(3.92)^{* * *}\end{array}$ & $\begin{array}{c}0.196 \\
(3.53)^{* * *}\end{array}$ & $\begin{array}{l}0.077 \\
(0.51)\end{array}$ \\
\hline Small states $(<1.5)$ & $\begin{array}{c}1.013 \\
(2.50)^{* *}\end{array}$ & & & \\
\hline Large states $(>40)$ & $\begin{array}{l}-0.169 \\
(0.65)\end{array}$ & $\begin{array}{l}-0.145 \\
(0.56)\end{array}$ & & \\
\hline Small states $A$ (from 0 to .5) & & $\begin{array}{c}1.179 \\
(2.25)^{* *}\end{array}$ & $\begin{array}{c}1.035 \\
(2.06)^{* *}\end{array}$ & $\begin{array}{c}1.024 \\
(2.75)^{* * *}\end{array}$ \\
\hline Small states B (from .5 to 1.5) & & $\begin{array}{l}0.308 \\
(1.12)\end{array}$ & & \\
\hline Constant & $\begin{array}{c}-18.906 \\
(3.77)^{* * *}\end{array}$ & $\begin{array}{c}-19.633 \\
(3.87)^{* * *}\end{array}$ & $\begin{array}{c}-15.379 \\
(3.13)^{* * *}\end{array}$ & $\begin{array}{c}-13.329 \\
(2.90)^{* * *}\end{array}$ \\
\hline No. of Observations & 285 & 285 & 285 & 285 \\
\hline No. of Countries & 153 & 153 & 153 & 153 \\
\hline R-squared & 0.41 & 0.42 & 0.36 & 0.37 \\
\hline
\end{tabular}

Absolute value of $t$ statistics in parentheses

*significant at 10\%;** significant at 5\%; *** significant at $1 \%$

Columns (1) to (3): panel random effects estimation; column (4): Pooled Least Squares estimation 
Table 4: Determinants of the skilled emigration rate (after age 22)

\begin{tabular}{|c|c|c|c|c|}
\hline & $(1)$ & $(2)$ & (3) & (4) \\
\hline Log population size & $\begin{array}{c}-0.189 \\
(2.00) * *\end{array}$ & $\begin{array}{c}-0.213 \\
(2.34) * *\end{array}$ & $\begin{array}{c}-0.206 \\
(3.05)^{* * *}\end{array}$ & $\begin{array}{c}-0.239 \\
(4.63) * * *\end{array}$ \\
\hline Log GDP per capita & $\begin{array}{c}4.731 \\
(4.01)^{* * *}\end{array}$ & $\begin{array}{c}5.019 \\
(4.24)^{* * *}\end{array}$ & $\begin{array}{c}4.216 \\
(3.62)^{* * *}\end{array}$ & $\begin{array}{c}4.075 \\
(3.70)^{* * *}\end{array}$ \\
\hline Log GDP per capita squared & $\begin{array}{c}-0.301 \\
(4.08)^{* * *}\end{array}$ & $\begin{array}{c}-0.318 \\
(4.29)^{* * *}\end{array}$ & $\begin{array}{c}-0.262 \\
(3.64)^{* * *}\end{array}$ & $\begin{array}{c}-0.263 \\
(3.83)^{* * *}\end{array}$ \\
\hline Oil exporting dummy & $\begin{array}{l}-0.446 \\
(1.34)\end{array}$ & $\begin{array}{l}-0.391 \\
(1.16)\end{array}$ & & \\
\hline Violation of property rights & $\begin{array}{c}0.510 \\
(2.81)^{* * *}\end{array}$ & $\begin{array}{c}0.455 \\
(2.52)^{* *}\end{array}$ & $\begin{array}{l}0.124 \\
(0.86)\end{array}$ & $\begin{array}{l}0.067 \\
(0.54)\end{array}$ \\
\hline Political stability & $\begin{array}{l}-0.392 \\
(1.89)^{*}\end{array}$ & $\begin{array}{l}-0.392 \\
(1.90)^{*}\end{array}$ & & \\
\hline Government effectiveness & $\begin{array}{c}0.976 \\
(3.49)^{* * *}\end{array}$ & $\begin{array}{c}0.931 \\
(3.35)^{* * *}\end{array}$ & & \\
\hline Religious fractionalization & $\begin{array}{c}0.953 \\
(2.37)^{* *}\end{array}$ & $\begin{array}{c}1.020 \\
(2.52)^{* *}\end{array}$ & $\begin{array}{c}1.103 \\
(2.63)^{* * *}\end{array}$ & $\begin{array}{c}1.191 \\
(3.76)^{* * *}\end{array}$ \\
\hline Linguistic links & $\begin{array}{c}0.704 \\
(3.30)^{* * *}\end{array}$ & $\begin{array}{c}0.645 \\
(3.04)^{* * *}\end{array}$ & $\begin{array}{c}0.715 \\
(3.33)^{* * *}\end{array}$ & $\begin{array}{c}0.597 \\
(3.73)^{* * *}\end{array}$ \\
\hline Distance from OECD (in log) & $\begin{array}{c}-0.388 \\
(3.83)^{* * *}\end{array}$ & $\begin{array}{c}-0.380 \\
(3.76)^{* * *}\end{array}$ & $\begin{array}{c}-0.459 \\
(4.52)^{* * *}\end{array}$ & $\begin{array}{c}-0.459 \\
(5.76)^{* * *}\end{array}$ \\
\hline Former colony of OECD country & $\begin{array}{c}0.813 \\
(3.27)^{* * *}\end{array}$ & $\begin{array}{c}0.882 \\
(3.65)^{* * *}\end{array}$ & $\begin{array}{c}0.902 \\
(3.73)^{* * *}\end{array}$ & $\begin{array}{c}0.667 \\
(3.58)^{* * *}\end{array}$ \\
\hline Year 2000 & $\begin{array}{c}0.220 \\
(3.92)^{* * *}\end{array}$ & $\begin{array}{c}0.227 \\
(4.04)^{* * *}\end{array}$ & $\begin{array}{c}0.199 \\
(3.66)^{* * *}\end{array}$ & $\begin{array}{l}0.097 \\
(0.67)\end{array}$ \\
\hline Small states $(<1.5)$ & $\begin{array}{c}1.018 \\
(2.63)^{* * *}\end{array}$ & & & \\
\hline Large states $(>40)$ & $\begin{array}{c}-0.173 \\
(0.69)\end{array}$ & $\begin{array}{c}-0.152 \\
(0.60)\end{array}$ & & \\
\hline Small states A (from 0 to .5) & & $\begin{array}{c}1.181 \\
(2.36)^{* *}\end{array}$ & $\begin{array}{c}0.998 \\
(2.07)^{* *}\end{array}$ & $\begin{array}{c}1.000 \\
(2.80)^{* * *}\end{array}$ \\
\hline Small states $B$ (from .5 to 1.5 ) & & $\begin{array}{l}0.371 \\
(1.39)\end{array}$ & & \\
\hline Constant & $\begin{array}{c}-17.699 \\
(3.66)^{* * *}\end{array}$ & $\begin{array}{c}-18.405 \\
(3.76)^{* * *}\end{array}$ & $\begin{array}{c}-14.290 \\
(3.01)^{* * *}\end{array}$ & $\begin{array}{c}-12.160 \\
(2.76)^{* * *}\end{array}$ \\
\hline No. of Observations & 285 & 285 & 285 & 285 \\
\hline No. of Countries & 153 & 153 & 153 & 153 \\
\hline R-squared & 0.41 & 0.42 & 0.36 & 0.37 \\
\hline
\end{tabular}

Absolute value of $t$ statistics in parentheses

*significant at $10 \%$; **significant at $5 \%$; ***significant at $1 \%$

Columns (1) to (3): panel random effects estimation; column (4): Pooled Least Squares estimation 
Table 5: Determinants of various emigration rates

(with interaction of country size and fractionalization)

\begin{tabular}{lcccccc}
\hline \hline & $(1)$ & $(2)$ & $(3)$ & $(4)$ & $(5)$ & $(6)$ \\
& Total & Skilled & Skill 22+ & Total & Skilled & Skill 22+ \\
\hline Log Population & -0.222 & -0.194 & -0.200 & -0.244 & -0.213 & -0.215 \\
& $(3.43)^{* * *}$ & $(2.99)^{* * *}$ & $(3.18)^{* * *}$ & $(5.05)^{* * *}$ & $(4.33)^{* * *}$ & $(4.53)^{* * *}$ \\
Log GDP per capita & 5.442 & 4.245 & 3.956 & 6.823 & 4.054 & 3.708 \\
& $(5.40)^{* * *}$ & $(3.56)^{* * *}$ & $(3.41)^{* * *}$ & $(6.67)^{* * *}$ & $(3.79)^{* * *}$ & $(3.59)^{* * *}$ \\
Log GDP per capita sq & -0.312 & -0.262 & -0.249 & -0.399 & -0.258 & -0.241 \\
& $(5.12)^{* * *}$ & $(3.67)^{* * *}$ & $(3.58)^{* * *}$ & $(6.48)^{* * *}$ & $(4.05)^{* * *}$ & $(3.91)^{* * *}$ \\
Oil exporting dummy & -0.562 & -0.724 & -0.681 & -0.560 & -0.706 & -0.665 \\
& $(1.69)^{*}$ & $(2.15)^{* *}$ & $(2.10)^{* *}$ & $(2.33)^{* *}$ & $(2.85)^{* * *}$ & $(2.78)^{* * *}$ \\
Religious fractionalization & 0.070 & 0.632 & 0.698 & 0.194 & 0.700 & 0.742 \\
& $(0.16)$ & $(1.44)$ & $(1.65)^{*}$ & $(0.59)$ & $(2.10)^{* *}$ & $(2.30)^{* *}$ \\
Relig. fract. x Small states & 1.929 & 1.727 & 1.505 & 1.792 & 1.865 & 1.652 \\
& $(3.09)^{* * *}$ & $(2.65)^{* * *}$ & $(2.40)^{* *}$ & $(3.83)^{* * *}$ & $(3.77)^{* * *}$ & $(3.46)^{* * *}$ \\
Linguistic & 0.678 & 0.687 & 0.585 & 0.592 & 0.599 & 0.510 \\
& $(3.26)^{* * *}$ & $(3.24)^{* * *}$ & $(2.87)^{* * *}$ & $(3.81)^{* * *}$ & $(3.75)^{* * *}$ & $(3.31)^{* * *}$ \\
Distance & -0.575 & -0.412 & -0.411 & -0.642 & -0.429 & -0.423 \\
& $(5.74)^{* * *}$ & $(3.85)^{* * *}$ & $(3.98)^{* * *}$ & $(7.88)^{* * *}$ & $(5.10)^{* * *}$ & $(5.21)^{* * *}$ \\
Year2000 & & & & & & \\
& 0.320 & 0.154 & 0.155 & 0.254 & 0.055 & 0.069 \\
Former colony & $(7.65)^{* * *}$ & $(2.63)^{* * *}$ & $(2.67)^{* * *}$ & $(1.82)^{*}$ & $(0.38)$ & $(0.51)$ \\
Constant & & 1.035 & 0.933 & & 0.794 & 0.712 \\
& & $(4.07)^{* * *}$ & $(3.81)^{* * *}$ & & $(4.08)^{* * *}$ & $(3.79)^{* * *}$ \\
& & -14.143 & -12.872 & -24.552 & -12.179 & -10.834 \\
No. of Observations & 310 & 310 & 310 & 310 & 310 & 310 \\
No. of Countries & 166 & 166 & 166 & 166 & 166 & 166 \\
R-squared & 0.55 & 0.45 & 0.43 & 0.54 & 0.46 & 0.44 \\
\hline \hline
\end{tabular}

Absolute value of $\mathrm{z}$ statistics in parentheses

*significant at $10 \%$; **significant at $5 \%$; ***significant at $1 \%$

Columns (1) to (3): panel random effects estimation; column (4) to (6): Pooled Least Squares estimation 
Table 6: Determinants of various emigration rates

(with interaction of country size and GDP per capita)

\begin{tabular}{|c|c|c|c|c|c|c|}
\hline & $\begin{array}{l}(1) \\
\text { Total }\end{array}$ & $\begin{array}{c}(2) \\
\text { Skilled }\end{array}$ & $\begin{array}{c}\text { (3) } \\
\text { Skill 22+ }\end{array}$ & $\begin{array}{c}(4) \\
\text { Total }\end{array}$ & $\begin{array}{c}(5) \\
\text { Skilled }\end{array}$ & $\begin{array}{c}(6) \\
\text { Skill 22+ }\end{array}$ \\
\hline Log population & $\begin{array}{c}-0.192 \\
(2.48) * *\end{array}$ & $\begin{array}{c}-0.189 \\
(2.53)^{* *}\end{array}$ & $\begin{array}{c}-0.184 \\
(2.57)^{* *}\end{array}$ & $\begin{array}{c}-0.276 \\
(4.97)^{* * *}\end{array}$ & $\begin{array}{c}-0.226 \\
(4.02)^{* * *}\end{array}$ & $\begin{array}{c}-0.215 \\
(3.98) * * *\end{array}$ \\
\hline GDP per capita & $\begin{array}{c}5.578 \\
(5.58)^{* * *}\end{array}$ & $\begin{array}{c}4.729 \\
(4.00)^{* * *}\end{array}$ & $\begin{array}{c}4.365 \\
(3.81)^{* * *}\end{array}$ & $\begin{array}{c}7.605 \\
(7.49)^{* * *}\end{array}$ & $\begin{array}{c}4.891 \\
(4.67)^{* * *}\end{array}$ & $\begin{array}{c}4.420 \\
(4.39)^{* * *}\end{array}$ \\
\hline GDP per capita sq. & $\begin{array}{c}-0.321 \\
(5.30)^{* * *}\end{array}$ & $\begin{array}{c}-0.291 \\
(4.10)^{* * *}\end{array}$ & $\begin{array}{c}-0.274 \\
(3.98)^{* * *}\end{array}$ & $\begin{array}{c}-0.445 \\
(7.27)^{* * *}\end{array}$ & $\begin{array}{c}-0.307 \\
(4.90)^{* * *}\end{array}$ & $\begin{array}{c}-0.283 \\
(4.69)^{* * *}\end{array}$ \\
\hline GDP per cap x small & $\begin{array}{c}0.122 \\
(2.78)^{* * *}\end{array}$ & $\begin{array}{c}0.093 \\
(2.08)^{* *}\end{array}$ & $\begin{array}{c}0.090 \\
(2.10)^{* *}\end{array}$ & $\begin{array}{c}0.067 \\
(2.16)^{* *}\end{array}$ & $\begin{array}{c}0.083 \\
(2.48)^{* *}\end{array}$ & $\begin{array}{c}0.083 \\
(2.58)^{* *}\end{array}$ \\
\hline Oil export & $\begin{array}{l}-0.484 \\
(1.35)\end{array}$ & $\begin{array}{c}-0.651 \\
(1.88)^{*}\end{array}$ & $\begin{array}{l}-0.614 \\
(1.85)^{*}\end{array}$ & $\begin{array}{c}-0.483 \\
(1.98)^{* *}\end{array}$ & $\begin{array}{c}-0.638 \\
(2.54)^{* *}\end{array}$ & $\begin{array}{c}-0.601 \\
(2.49)^{* *}\end{array}$ \\
\hline Religious fractionalization & $\begin{array}{l}0.510 \\
(1.14)\end{array}$ & $\begin{array}{c}1.041 \\
(2.44)^{* *}\end{array}$ & $\begin{array}{c}1.058 \\
(2.59)^{* * *}\end{array}$ & $\begin{array}{c}0.651 \\
(2.11)^{* *}\end{array}$ & $\begin{array}{c}1.163 \\
(3.67)^{* * *}\end{array}$ & $\begin{array}{c}1.154 \\
(3.79) * * *\end{array}$ \\
\hline Linguistic & $\begin{array}{c}0.674 \\
(2.99)^{* * *}\end{array}$ & $\begin{array}{c}0.680 \\
(3.13)^{* * *}\end{array}$ & $\begin{array}{c}0.583 \\
(2.80)^{* * *}\end{array}$ & $\begin{array}{c}0.568 \\
(3.60)^{* * *}\end{array}$ & $\begin{array}{c}0.574 \\
(3.55)^{* * *}\end{array}$ & $\begin{array}{c}0.492 \\
(3.17) * * *\end{array}$ \\
\hline Distance & $\begin{array}{c}-0.567 \\
(5.32)^{* * *}\end{array}$ & $\begin{array}{c}-0.406 \\
(3.71)^{* * *}\end{array}$ & $\begin{array}{c}-0.407 \\
(3.87)^{* * *}\end{array}$ & $\begin{array}{c}-0.630 \\
(7.60)^{* * *}\end{array}$ & $\begin{array}{c}-0.424 \\
(4.97)^{* * *}\end{array}$ & $\begin{array}{c}-0.420 \\
(5.12)^{* * *}\end{array}$ \\
\hline Year2000 & $\begin{array}{c}0.314 \\
(7.83)^{* * *}\end{array}$ & $\begin{array}{c}0.154 \\
(2.67)^{* * *}\end{array}$ & $\begin{array}{c}0.154 \\
(2.68)^{* * *}\end{array}$ & $\begin{array}{c}0.250 \\
(1.75)^{*}\end{array}$ & $\begin{array}{l}0.051 \\
(0.35)\end{array}$ & $\begin{array}{l}0.065 \\
(0.47)\end{array}$ \\
\hline Former colony & & $\begin{array}{c}1.039 \\
(3.91)^{* * *}\end{array}$ & $\begin{array}{c}0.920 \\
(3.60)^{* * *}\end{array}$ & & $\begin{array}{c}0.837 \\
(4.18)^{* * *}\end{array}$ & $\begin{array}{c}0.732 \\
(3.80)^{* * *}\end{array}$ \\
\hline Constant & $\begin{array}{c}-21.378 \\
(5.09)^{* * *}\end{array}$ & $\begin{array}{c}-16.441 \\
(3.33)^{* * *}\end{array}$ & $\begin{array}{c}-14.960 \\
(3.12)^{* * *}\end{array}$ & $\begin{array}{c}-27.558 \\
(6.56)^{* * *}\end{array}$ & $\begin{array}{c}-15.700 \\
(3.61)^{* * *}\end{array}$ & $\begin{array}{c}-13.974 \\
(3.34)^{* * *}\end{array}$ \\
\hline No. of Observations & 310 & 310 & 310 & 310 & 310 & 310 \\
\hline No. of Countries & 166 & 166 & 166 & 166 & 166 & 166 \\
\hline R-squared & 0.51 & 0.45 & 0.44 & 0.53 & 0.44 & 0.43 \\
\hline
\end{tabular}


Table 7: Determinants of various emigration rates

(with interaction of country size and squared per capita GDP)

\begin{tabular}{|c|c|c|c|c|c|c|}
\hline & $\begin{array}{c}(1) \\
\text { Total }\end{array}$ & $\begin{array}{c}(2) \\
\text { Skilled }\end{array}$ & $\begin{array}{c}\text { (3) } \\
\text { Skill 22+ } \\
\end{array}$ & $\begin{array}{c}(4) \\
\text { Total }\end{array}$ & $\begin{array}{c}(5) \\
\text { Skilled }\end{array}$ & $\begin{array}{c}(6) \\
\text { Skill 22+ }\end{array}$ \\
\hline Log population & $\begin{array}{c}-0.165 \\
(2.22)^{* *}\end{array}$ & $\begin{array}{c}-0.176 \\
(2.40)^{* *}\end{array}$ & $\begin{array}{c}-0.173 \\
(2.45)^{* *}\end{array}$ & $\begin{array}{c}-0.274 \\
(4.95)^{* * *}\end{array}$ & $\begin{array}{c}-0.225 \\
(4.02)^{* * *}\end{array}$ & $\begin{array}{c}-0.214 \\
(3.97)^{* * *}\end{array}$ \\
\hline GDP per capita & $\begin{array}{c}5.682 \\
(5.73)^{* * *}\end{array}$ & $\begin{array}{c}4.802 \\
(4.09)^{* * *}\end{array}$ & $\begin{array}{c}4.437 \\
(3.89)^{* * *}\end{array}$ & $\begin{array}{c}7.687 \\
(7.58)^{* * *}\end{array}$ & $\begin{array}{c}4.999 \\
(4.79)^{* * *}\end{array}$ & $\begin{array}{c}4.527 \\
(4.52)^{* * *}\end{array}$ \\
\hline GDP per capita sq. & $\begin{array}{c}-0.330 \\
(5.49)^{* * *}\end{array}$ & $\begin{array}{c}-0.297 \\
(4.20)^{* * *}\end{array}$ & $\begin{array}{c}-0.280 \\
(4.08)^{* * *}\end{array}$ & $\begin{array}{c}-0.450 \\
(7.36)^{* * *}\end{array}$ & $\begin{array}{c}-0.314 \\
(5.02)^{* * *}\end{array}$ & $\begin{array}{c}-0.290 \\
(4.82)^{* * *}\end{array}$ \\
\hline GDP squared $x$ small & $\begin{array}{c}0.016 \\
(3.47)^{* * *}\end{array}$ & $\begin{array}{c}0.012 \\
(2.39)^{* *}\end{array}$ & $\begin{array}{c}0.011 \\
(2.40)^{* *}\end{array}$ & $\begin{array}{c}0.008 \\
(2.23)^{* *}\end{array}$ & $\begin{array}{c}0.009 \\
(2.54)^{* *}\end{array}$ & $\begin{array}{c}0.009 \\
(2.65)^{* * *}\end{array}$ \\
\hline Oil export & $\begin{array}{l}-0.484 \\
(1.37)\end{array}$ & $\begin{array}{l}-0.651 \\
(1.89)^{*}\end{array}$ & $\begin{array}{l}-0.615 \\
(1.86)^{*}\end{array}$ & $\begin{array}{c}-0.488 \\
(2.01)^{* *}\end{array}$ & $\begin{array}{c}-0.646 \\
(2.58)^{* *}\end{array}$ & $\begin{array}{c}-0.608 \\
(2.52)^{* *}\end{array}$ \\
\hline Religious fractionalization & $\begin{array}{l}0.519 \\
(1.18)\end{array}$ & $\begin{array}{c}1.051 \\
(2.48)^{* *}\end{array}$ & $\begin{array}{c}1.067 \\
(2.62)^{* * *}\end{array}$ & $\begin{array}{c}0.656 \\
(2.12)^{* *}\end{array}$ & $\begin{array}{c}1.167 \\
(3.69)^{* * *}\end{array}$ & $\begin{array}{c}1.159 \\
(3.81)^{* * *}\end{array}$ \\
\hline Linguistic & $\begin{array}{c}0.688 \\
(3.10)^{* * *}\end{array}$ & $\begin{array}{c}0.690 \\
(3.18)^{* * *}\end{array}$ & $\begin{array}{c}0.592 \\
(2.85)^{* * *}\end{array}$ & $\begin{array}{c}0.570 \\
(3.61)^{* * *}\end{array}$ & $\begin{array}{c}0.575 \\
(3.56)^{* * *}\end{array}$ & $\begin{array}{c}0.494 \\
(3.18)^{* * *}\end{array}$ \\
\hline Distance & $\begin{array}{c}-0.586 \\
(5.55)^{* * *}\end{array}$ & $\begin{array}{c}-0.410 \\
(3.76)^{* * *}\end{array}$ & $\begin{array}{c}-0.411 \\
(3.92)^{* * *}\end{array}$ & $\begin{array}{c}-0.629 \\
(7.60)^{* * *}\end{array}$ & $\begin{array}{c}-0.424 \\
(4.97)^{* * *}\end{array}$ & $\begin{array}{c}-0.420 \\
(5.12)^{* * *}\end{array}$ \\
\hline Year2000 & $\begin{array}{c}0.310 \\
(7.77)^{* * *}\end{array}$ & $\begin{array}{c}0.151 \\
(2.62)^{* * *}\end{array}$ & $\begin{array}{c}0.151 \\
(2.63)^{* * * *}\end{array}$ & $\begin{array}{c}0.248 \\
(1.74)^{*}\end{array}$ & $\begin{array}{l}0.049 \\
(0.34)\end{array}$ & $\begin{array}{l}0.063 \\
(0.46)\end{array}$ \\
\hline Former colony & & $\begin{array}{c}1.022 \\
(3.87)^{* * *}\end{array}$ & $\begin{array}{c}0.904 \\
(3.57)^{* * *}\end{array}$ & & $\begin{array}{c}0.845 \\
(4.25)^{* * *}\end{array}$ & $\begin{array}{c}0.738 \\
(3.86)^{* * *}\end{array}$ \\
\hline Constant & $\begin{array}{c}-21.911 \\
(5.25)^{* * *}\end{array}$ & $\begin{array}{c}-16.807 \\
(3.40)^{* * *}\end{array}$ & $\begin{array}{c}-15.320 \\
(3.20)^{* * *}\end{array}$ & $\begin{array}{c}-27.902 \\
(6.62)^{* * *}\end{array}$ & $\begin{array}{c}-16.135 \\
(3.71)^{* * *}\end{array}$ & $\begin{array}{c}-14.410 \\
(3.45)^{* * *}\end{array}$ \\
\hline No. of Observation & 310 & 310 & 310 & 310 & 310 & 310 \\
\hline No of Countries & 166 & 166 & 166 & 166 & 166 & 166 \\
\hline R-squared & 0.51 & 0.44 & 0.43 & 0.53 & 0.44 & 0.43 \\
\hline
\end{tabular}


${ }^{1}$ A similar work can be found in Dumont and Lemaître (2005) who provide emigration rates for about 100 countries in 2000. The correlation between Docquier-Marfouk's and DumontLemaître's estimates varies between 91 percent and 88 percent depending on the human capital indicators used for residents.

${ }^{2}$ Mexican-born individuals who arrived in the US at age 5 or 10 and then graduated from US high-education institutions later on are counted as high-skill Mexican immigrants.

${ }^{3}$ At some point, the impact becomes negative, i.e., further increases in per capita income reduce migration rates. Even if the income differential with host countries remains constant, as income increases, the marginal value of living in one's culture and with one's friends and family rises relative to that of income. This provides another reason for the reduction in migration rates.

${ }^{4}$ This may be due to the fact that greater government effectiveness is also likely to i) promote trade, which is likely to require source country individuals to live temporarily abroad (such as under Mode IV of the GATS); and ii) result in lower costs of obtaining the documents required to leave the country, and the lower migration costs might result in an increase in the emigration of financially constrained individuals. 